\title{
The Needs of Character Education Based on Fairy-tale Textbook Development for Junior High Students in Semarang Regency
}

\section{A. Azizah ${ }^{1,2}$, J. Nurkamto2, S. Suwandi², and M. Rohmadi²}

${ }^{1}$ Indonesian Language and Literature Department, Faculty of Teacher Training and Education, Islamic University of Sultan Agung, Jalan Kaligawe Raya KM 4, Semarang 50112, Central Java, Indonesia

${ }^{2}$ Indonesian Language Education Department, Faculty of Teacher Training and Education, Sebelas Maret University, Jalan Ir. Sutami No 36A, Surakarta 57126, Central Java, Indonesia

\section{Abstract}

This research is aimed at describing teachers' and students' needs in terms of character education based on fairy-tale textbook development. It is intended to discover the level of junior high teachers' and students' needs regarding textbooks, especially in

Corresponding Author:

A. Azizah

aidaazizah@unissula.ac.id

Received: 6 April 2018

Accepted: 3 May 2018

Published: 26 July 2018

Publishing services provided by Knowledge E

(c) A. Azizah et al. This article is distributed under the terms of

the Creative Commons

Attribution License, which permits unrestricted use and redistribution provided that the original author and source are credited.

Selection and Peer-review under the responsibility of the ISLLE 2017 Conference Committee.
Semarang regency. The method used is qualitative-descriptive research. The data collection was conducted by carrying out interviews, observation, questionnaires, and analyses. Data analysis was an interactive-cycle model through a data presentation and a conclusion. The results showed that the teachers and students in junior high schools need sufficient character education based on fairy-tale textbooks, which requires the following aspects: content, presentation, language and readability, and graphics. Based on the findings, it is suggested that the availability of character education based on fairy-tale textbooks for teachers and students in junior high schools in Semarang needs developing.

Keywords: character education, fairy tale textbook development, interactive-cycle model

\section{Introduction}

Indonesian language teaching consists of four skill aspects of language learning and literature learning. One of the standard competences of literature learning aspects mentioned in the standard contents of the Indonesian Language curriculum is appreciative learning through fairy tales. Literature learning has an important role for one's life since it can help increase one's ability and intellectual maturity, and arouse one's creativity to produce literary works. 
Appreciative learning through fairy tales has some advantages: for example, it can increase someone's love toward literary appreciation and it can be used to educate children since it teaches many moral values. Through appreciative learning, learners can predict the characters of each actor in a story, which can be adopted easily by them as the literary works are conveyed without forcing the readers to accept them.

Characters in a story can provide examples for learners in real life and can help children to control their emotions and their social interaction skills that enable to link them with their own experience [1]. One of children's characteristics is a tendency to imitate and identify themselves with the characters they adore. Through fairy tales, learners will find it easy to identify the qualities of each character that is presented through the events in the story [2]. Thus, we can subsequently know the characters of the learners from this learning activity. Nikolajeva [3] stated that characters performed in traditional stories, namely fairy tales, can be used as media in conveying the ideas and opinions of the writers. The old fairy tales coming from regions in Indonesia can easily become the targets of where the character-based education through the heroic characters of the stories can be found.

The process of learning the Indonesian language and literature is supposed to use the most suitable materials so that the learning goals can be achieved well. The process of selection and the use of the textbooks as the proper learning sources are the supporting factors in the success of the learning process. This is in line with Tomlinson [4], who proposed that textbooks have an important role as a hidden curriculum that gives directions in the teaching and learning process. Textbooks are one of the important elements in Indonesian language and literature learning. Through education, textbooks are the best instruments to have a big influence on national unity [5]. This is in line with Skuy et al. [6], who state that teaching materials are one of the basic and crucial learning components so proper textbook selection must be applied in literature learning. This should be done since literary textbooks are included as facilitators of important skill aspects. Through appreciative learning activities, someone will be able to find new ideas and knowledge from any written products expressed through events in fairy tales. Writing is basically a medium to express ideas or opinions so that they are understood and accepted by other people. In this case, it can be said that fairy tales are communication media that are effective and efficient in reaching broad communities.

According to Elmaghfiroh [7], textbooks are a record of racial thoughts that are set to fulfill instructional intentions and purposes. The Ministry of National Education Regulation No 22008 Chapter 1 Section 1 states that textbooks are compulsory references used in the educational units of elementary and secondary schools or even 
colleges that contain learning materials for the efforts to increase faith in, and fear of, God, nobility, and personality, to increase technology and science mastery, to increase sensitivity and aesthetic ability, and to increase aesthetics and health, which have been arranged based on the standards of national education.

Some textbook components attempt to give facilities to students so that they can improve their learning results, such as directions, learning purposes, material contents, exercises, and summaries [8].

Based on the observation and interviews with Indonesian junior high language teachers in Semarang, it was clear that in reality, the teachers only gave a small portion of the material presentation, and the components of the textbooks used were still limited to the short materials that do not explore the students' potentials. Further, the educational content of the characters in the fairy tales was also limited, whereas character education-based learning is absolutely needed given that the educational goals are mentioned in the national educational goals. It is expected that textbooks and a program of scoring clarification for each child have good qualities suited to what is expected in the curriculum [9]. The availability and quality of the fairy tale textbooks used by junior high teachers in Semarang are still limited to the course textbooks provided by the government.

Literary textbooks that are able to develop students' characters are still rarely found. This suggests that character-based fairy tale textbooks need to be developed for junior high students. This research is designed to describe the level of the needs of junior high students and teachers in Semarang regency in terms of the development of character education based on fairy tale textbooks.

\section{Methods}

\subsection{Research methodology}

This research used a qualitative-descriptive method. In this research, the aim is to describe the level of the needs of junior high students and teachers in Semarang regency regarding the development of character education based on fairy tale textbooks. The subjects were students and teachers at four public junior high schools in Semarang regency, that is, SMP Negeri 2 Sumowono, SMP Negeri 2 Bandungan Satu Atap, SMP Negeri 1 Sumowono, and SMP Negeri 1 Ungaran. 


\subsection{Data collection}

The technique of data collection was conducted through observation, interviews, questionnaires, and analyses of the fairy tale textbooks.

\subsection{Data analysis}

The technique of data analysis used in the research was an interactive-cycle model in the form of data presentation and a conclusion.

\section{Results}

We discovered that the teachers had not arranged and adapted the textbooks, so they used course books provided by the government and storybooks. These books are written by different authors. The books did not fulfill their expectation as mentioned in the needs analysis. The students and teachers have some needs regarding the development of character education based on fairy tale textbooks.

\subsection{Students' needs regarding character education based on fairy tale textbooks}

The needs analysis of the students was derived from the results of interviews and questionnaires given to the junior high students in four schools, namely SMP Negeri 2 Sumowono, SMP Negeri 2 Satu Atap Bandungan, SMP Negeri 1 Sumowono, and SMP Negeri 1 Ungaran. The results of the interviews and questionnaires are summarized from needs analysis obtained from the students' views and opinions, that is, appreciative learning through fairy tales is an interesting learning activity that is able to increase the interest and motivation of the students to join the lesson. However, some students mentioned that the books used during the lessons were not comprehensive enough and the books consisting of fairytales were very limited, so the lessons were monotonous. This happened because the appreciative learning through fairy tales was only taught theoretically. Further, the lack of teaching materials about fairy tales caused the students to lose their enthusiasm in participating in the lessons. Therefore, fairy tale textbooks are needed by students in the teaching and learning process [10].

Based on the findings about the importance of fairy tale textbooks for junior high students, it can be concluded that the books are greatly needed. The content of the 
books is considered to be comprehensive if it provides coherent and systematic material explanation, and is accompanied by directions and examples before practice activities and evaluation in order to make the students feel it is easy to learn. Learning from the aforementioned data, it shows that the sources that have been used in the learning process so far are only sources provided by the government, textbooks that contain all the subject materials for a year. Schools have not used sources focusing on a literary work about fairy tale appreciation.

\subsection{Teachers' needs regarding character education based on fairy tale textbooks}

The needs analysis from the teachers' side was derived from the interviews and questionnaires conducted by teachers of the Indonesian language in four junior high schools, namely: SMP Negeri 2 Sumowono, SMP Negeri 2 Satu Atap Bandungan, SMP Negeri 1 Sumowono, and SMP Negeri 1 Ungaran. The results of the interviews and questionnaires were obtained from the teachers' opinions and views. They mentioned that the books used in the learning process were considered to be not fully effective due to the brief theories explained in the textbooks. The books are not accompanied by learning steps presented by examples whereas they are considered to be important for students who are in the process of learning to be independent. The comprehensive explanations and examples in the books will help the students learn independently without guidance from the teachers.

Unfortunately, most books used in the schools only contained short theories continued to assignments. Meanwhile, the supporting textbooks used by the teachers were only theoretical books that were followed by examples of fairy tale collections. Sometimes the books only consist of fairy tales. By seeing these drawbacks, the teachers usually give an alternative by asking the students to search fairy tales on the Internet, especially fairy tales coming from their own region.

Literature learning should not only be taught through theoretical activities. However, it should relate to the material substances that are essential for the students' character development and ways of thinking. Therefore, teachers expect to have more comprehensive books, which not only present theoretical aspects of fairy tales but also describe the ways to analyze fairy tale structures, the ways to find interesting aspects in fairy tales, and the ways to show the relevance of fairy tales to present-day life. With the existence of the books, it is expected that it is not only the teachers who have the textbooks but also the students, so that the teaching and learning process of 
fairy tales will be more effective and efficient. In addition, the books can be used to increase students' interest in appreciating fairy tales.

Based on the results of the needs analysis according to the teachers and students derived from observations by distributing questionnaires, and interviews with Indonesian language teachers, it was revealed that: first, students at junior high schools need fairy tale textbooks for their references in Indonesian language learning. Second, fairy tale textbooks should contain: (1) theories of fairy tales; (2) theories of fairy tale structures; (3) theories of interesting aspects in fairy tales; (4) theories of fairy tale relevance; (5) theories of character educational values; and (6) explanation about fairy tales accompanied by procedures of fairy tale appreciation. Third, the textbooks use a communicative language and have an interesting presentation. Fourth, the textbooks support other literature learning materials, such as short stories, novels, and other literary works. Fifth, the textbooks emphasize character-building values. Some findings in the needs analysis according to the teachers and students mentioned before will be used as guidance in a draft/prototype arrangement of character education based on fairy tale textbooks in the following research.

\section{Conclusion}

The results of the study show that students and teachers need adequate fairy tale textbooks, supported by various components: material contents, character educationbased values, language, and readability. The content of fairy tale textbooks includes explanation of the materials in a coherent and systematic way, namely fairy tale theories, fairy tale structures, interesting aspects in fairy tales, fairy tale relevance, and character education values. Therefore, it is suggested that the character education based on fairy tale textbooks in junior high needs developing.

\section{References}

[1] Hohr, H. (2000). Dynamic aspects of fairy tales: Social and emotional competence through fairy tales. Scandinavian Journal of Educational Research, vol. 44, no. 1, pp. 89-103.

[2] Bryan, L. (2005). Once upon a time: A Grimm approach to character education. Journal of Social Studies Research, vol. 29, no. 1, pp. 3-6.

[3] Nikolajeva, M. (2003). The Rethoric of Character in Children's Literature. Oxford: The Scarecrow Press. 
[4] Tomlinson, B. (2008). English Language Learning Materials: A Critical Review. London: Continum.

[5] Sitepu, B. P. (2012). Penulisan Buku Teks Pelajaran. Bandung: PT. Remaja Rosdkarya.

[6] Skuy, M., Young, S., Ajam, A., et al. (2001). Instrumental enrichment as a vehicle for teachers in implementing outcomes based education in South Africa. International Journal of Special Education, vol. 16, no. 2, pp. 1-15.

[7] Elmaghfiroh. (2009). The Textbook for Teacher. London: Continum.

[8] Dick, W. and Carey, L. (1990). The Systematik Design of Instruction (Second edition). London: Scoot, Foresman and Company.

[9] Benson, G. C. and Engeman, T. S. (1974). Practical possibilities in American moral education: a comparison of values clarification and the character education curriculum. Journal of Moral Education, vol. 4, no. 1, pp. 53-59.

[10] Nikolajeva, M. (2003). The Rethoric of Character in Children's Literature. Oxford: The Scarecrow Press. 